\title{
WYBRANE KOMPONENTY WSPÓŁCZESNEJ MENTALNOŚCI KOREAŃSKIEJ ZWIAZZANE Z GRZECZNOŚCIĄ
}

\begin{abstract}
Wstęp
Tradycyjne kultury (konfucjańska oraz buddyjska) w Korei zetknęły się i poprzenikały z kulturami zachodnimi (szczególnie amerykańska) sprowadzonymi na Półwysep Koreański w XX w., w efekcie czego wytworzyła się nowa wyjątkowa kultura. Mimo że w dobie globalizacji kultura i zwyczaje stopniowo zmieniają się w Korei Południowej, sporo przejawów w mentalności pozostało niezmiennych. Z tej perspektywy honoryfikatywność widoczna w języku koreańskim jest jedną z najważniejszych jego cech, choć samo zjawisko grzeczności językowej ma charakter uniwersalny i pojawia się we wszystkich językach i kulturach.

Język koreański jest jednym z niewielu języków z wyraźnym systemem honoryfikatywności. Kiedy Koreańczycy rozmawiają po koreańsku, muszą pamiętać o wieku i statusie społecznym podmiotu wypowiedzi, odbiorcy oraz nadawcy, by dobrać odpowiednie formy werbalne (gramatycznie i leksykalnie) oraz formy niewerbalne (ekspresję i gesty). Sposoby wyrażania honoryfikatywności koreańskiej różnią się w zależności od wszystkich składników aktów komunikacji oraz aktów mowy. Bez honoryfikatywności można wprawdzie stworzyć komunikat po koreańsku, ale pełna komunikacja jest bez niej niemożliwa.

W kulturze koreańskiej ludzie komunikują się inaczej niż Polacy, więc mimo znajomości języka koreańskiego grzeczność stanowi dla nie-Koreańczyków interesujące zagadnienie, które nieraz trudno zrozumieć, a nawet zaakceptować ${ }^{1}$. Wynika to przede wszystkim z tego, że Koreańczycy i Polacy różnie się zachowują w podobnych sytuacjach oraz różnie rozumieją adekwatne do danej sytuacji zachowanie. Pojęcie grzeczności w obu narodach jest odmiennie rozumiane, co wynika z innego rodzaju relacji społecznych, jakie tworzą. Grzeczność można rozumieć jako sposób okazywania szacunku drugiemu człowiekowi, który w Korei jest uwarunkowany wiekiem danej osoby („charakter pionowy”), a w Polsce zależy od relacji między osobami i łączącej ich zażyłości (,charakter poziomy”).

Przyczyną różnic w okazywaniu grzeczności pomiędzy Koreańczykami i Polakami jest z jednej strony język z punktu widzenia mikro, z drugiej zaś kultura z punktu

ORCID: 0000-0003-1135-4923, DOI: 10.4467/23538724GS.20.060.13500

1 M. Jacoby, Korea Południowa. Republika synwiotón, Warszawa 2018.
\end{abstract}


widzenia makro. Na przykład Koreańczycy dłużej pracują niż większość narodów świata $^{2}$. Akceptacja tego stanu rzeczy ze strony koreańskiego społeczeństwa ma związek z grzecznościa. Zasady te nieustannie się zmieniają wraz z tym, jak zmienia się mentalność Koreańczyków, na którą niewątpliwy wpływ w XX w. miał rozwój gospodarczy kraju.

\section{Współczesna historia Korei Południowej i sukces rozwoju gospodarczego}

Od końca XIX w. przez cały wiek XX w historii Korei dokonywały się burzliwe zmiany. Straciła niepodległość na 35 lat (od $1910^{3}$ do 1945 r.) i została japońska kolonią. Japonia wprowadziła w Korei europejską strukturę społeczną i zainwestowała w infrastrukturę koreańską. Miało to na celu ułatwianie dominacji japońskiej w zajętym kraju ${ }^{4}$. Korea odzyskała wolność po kapitulacji Japonii ${ }^{5}$, lecz nadal trwały konflikty i istniały problemy, które wywołały zamęt tuż przed wojną koreańska, w latach 1946-1950.

Po II wojnie światowej na całym świecie panował konflikt ideologiczny, który nie ominął także Korei. Korea była ofiarą II wojny światowej, ze względu na swoja ważne strategicznie położenie ${ }^{6}$ Korea Południowa znalazła się pod okupacją USA, a Korea Północna pod okupacją ZSRR. Następnym etapem historii Korei była wojna koreańska (lata 1950-1953). Wzięło w niej udział 16 państw, więc można powie-

2 OECD, Average annual hours actually worked per worker 2004-2016, https://stats.oecd.org/Index.aspx?DataSetCode=ANHRS (dostęp: 15.01.2021).

3 W 1392 r. Seong-Gye Yi przejął władzę i zmienił nazwę kraju na Joseon (조선). Wcześniej istniał kraj zwany Goryeo. Państwo Joseon istniało przez prawie 600 lat, od 1392 do 1897 r. T. Goban-Klas, Korea. Historia i wspótczesność. Od pustelnicæego królestwa do azjatyckiego tygrysa, Toruń 2006, s. 37. Jednak pod koniec XIX w. rozpoczęła się inwazja mocarstw na Joseon. Młodzi intelektualiści z Joseon próbowali się zmodernizować. W tym czasie Joseon zmienił się na Cesarstwo Daehan (대한제 국), które trwało od 1897 do 1910 r. Jednak wszystkie próby reform i rozwoju nie powiodły się, w końcu Japonia dokonała aneksji Korei, która stała się tym samym prowincja Cesarstwa Wielkiej Japonii. Ibidem, s. 52-53.

4 G. Strnad, W.J. Dziak, Republika Korei. Zarys ewolucji systemu politycznego, Warszawa 2011, s. 14.

5 W dniu 14 sierpnia 1945 r. cesarz zdecydował się na kapitulację w II wojnie światowej. Następnego dnia japoński cesarz w przemówieniu radiowym poinformował, że Cesarstwo Japońskie poddało się aliantom. Z tego powodu Koreańskie Narodowe Święto Niepodległości obchodzone jest 15 sierpnia. Oficjalnie jednak II wojna światowa skończyła się 2 września 1945 r., kiedy Cesarstwo Wielkiej Japonii podpisało akt bezwarunkowej kapitulacji; J.W. Hall, Japonia od czasów najdawniejszych do dziisiaj, Warszawa 1979, s. 287; J. Tubielewicz, Historia Japonii, Warszawa 1984, s. 422-423.

6 W historii lokalizacja Półwyspu Koreańskiego zawsze miała znaczenie jako wejście do Pacyfiku dla Chin lub Rosji, dla Japonii wręcz przeciwnie - ma znaczenie wejścia na kontynent. Z tego powodu, kiedy Japonia najechała Koreę, najpierw wezwała ją do otwarcia drogi do Chin. 
dzieć, że stała się niemal kolejną wojną światową. Ten konflikt zbrojny bywa także nazywany ,zapomnianą wojną”, ponieważ wybuchła ona między II wojną światową a wojną wietnamska, co skutkowało tym, że uwaga innych krajów skupiała się tylko na tych dwóch konfliktach. Od tego czasu aż do dziś Korea jest podzielona na część południową oraz północną. Po wojnie koreańskiej (27 lipca 1953 r.) została ustanowiona linia demarkacyjna (ang. Military Demarcation Line ${ }^{7}$ ) między Koreą Południową a Koreą Północną. Wzdłuż tej linii, $2 \mathrm{~km}$ na południe i $2 \mathrm{~km}$ na północ, ustanowiono strefę zdemilitaryzowana, liczącą łącznie $4 \mathrm{~km}$. Zadaniem strefy jest ograniczenie fizycznego i wzrokowego kontaktu sił między dwiema stronami, co ma zmniejszać ryzyko, czyli hamować niekontrolowane wznowienie konfliktu ${ }^{8}$. Ten obszar nazywany jest „koreańską strefą zdemilitaryzowaną” (ang. Korean Demilitarized Zone ${ }^{9}$ ), chociaż na tym terytorium zawsze były i są nadal posterunki straży z uzbrojonymi żołnierzami.

Wojna odcisnęła piętno i zostawiła dużą ranę na duszy koreańskiej, dlatego ponad pół wieku od zakończenia działań zbrojnych ślady tego konfliktu nadal tkwią w świadomości Koreańczyków. Po wojnie Korea Południowa była jeszcze przez 27 lat (1961-1988) krajem pod dyktaturą wojskowa. Takie wydarzenia historyczne kształtowały współczesną mentalność koreańskiego społeczeństwa poprzez różne czynniki (politykę, religię, ekonomię, język itp.). Na ów proces ogromny wpływ miał również rozwój gospodarczy Korei Południowej w XX w. Opierał sie on na tradycyjnej mentalności Koreańczyków, na kulturze wynikającej z filozofii konfucjańskiej. Jednak te dawne elementy także ulegały przemianom w toku współczesnej historii.

Korea Południowa po wojnie koreańskiej należała do najbiedniejszych krajów na świecie. Była gospodarczo bardzo zrujnowana, tradycyjna gospodarka pozostawało drobne rolnictwo. Ubóstwo trwało aż do początku lat 60 . XX w. ${ }^{10}$ Natomiast dziś Korea Południowa stała się członkiem grupy G2011, w 2016 r. zajmowała 11. miejsce

$7 \mathrm{~W}$ języku koreańskim gunsa bungyesun (군사분계선) lub byujeonsun (휴전선). Hyujeonsun ma znaczenie 'linia rozejmu’. Przebiega ona w poprzek Półwyspu Koreańskiego wzdłuż 38. równoleżnika. Linia 38. równoleżnika (kor. sampalsun) istniała od zakończenia II wojny światowej do wybuchu wojny koreańskiej; J.P. Rurarz, Historia Korei, Warszawa 2009, s. 380.

8 Ibidem, s. 380-381.

9 W języku koreańskim bimujang jidae (비무장지 대), natomiast często Koreańczycy mówia o strefie: 디엠제트 (ang. Demilitarized Zone - DMZ).

10 M. Kightley, Południowokoreański cud gospodarcsy w świetle koncepiji čłowieka gospodarujacego [w:] Korea w oczach Polaków, red. J. Włodarski, K. Zeidler, M. Burdelski, Gdańsk 2012, s. 369.

11 To grupa krajów, do której należy 19 państw (Arabia Saudyjska, Argentyna, Australia, Brazylia, Chiny, Francja, Indie, Indonezja, Japonia, Kanada, Korea Południowa, Meksyk, Niemcy, Republika Południowej Afryki, Rosja, Stany Zjednoczone, Turcja, Wielka Brytania, Włochy) i Unia Europejska. Grupa ma na celu dyskusję nad wspólną polityką finansową (zwłaszcza w kontekście międzynarodowego kryzysu gospodarczego). Obecnie łączny PKB tych krajów wynosi 85\% wartości światowej i odpowiada za 80\% światowego handlu, dlatego kwestie określone w G20 maja duży wpływ na cały świat. 
na świecie pod względem generowanego $\mathrm{PKB}^{12}$, a kilka firm koreańskich należy do najsilniejszych koncernów na świecie, np. Samsung, Hyundai, LG i KIA ${ }^{13}$.

W 1955 r., krótko po zakończeniu wojny koreańskiej, Komitet ONZ ds. Dalekiego Wschodu opublikował Raport ekonomiczny Azji i Dalekiego Wschodu ${ }^{14}$. Według raportu w 1955 r. w Azji znajdowały się tylko trzy kraje o dużym potencjale przemysłowym: Chiny, Indie i Japonia. W tym czasie produkt krajowy brutto Korei Południowej wynosił niecałe 100 USD na osobę ${ }^{15}$. W latach 50. XX w. większa część importu była finansowana z pomocy zagranicznej, głównie ze strony Stanów Zjednoczonych. W maju 1961 r. koreańska armia dokonała zamachu stanu. Dyktatura wojskowa trwała od tego momentu aż do 1987 r. Dopiero w 1993 r. władzę w Korei Południowej po raz pierwszy objął cywilny prezydent ${ }^{16}$. Dyktatura spowodowała z jednej strony brak wolności politycznej, z drugiej strony okazała się korzystna dla wzrostu ekonomicznego. Rząd wojskowy zdecydował, że absolutnym priorytetem jest rozwój gospodarczy, zaś Koreańczycy uważali działanie na rzecz rozwoju kraju za swój najważniejszy obowiązek. Pokolenie, które urodziło się w latach 50. i 60. XX w. jest zwane „pokoleniem industrializacji”. Korea Południowa rozpoczęła realizację strategii ukierunkowanej na eksport, przyciagała inwestycje zagraniczne i zachęcała Koreańczyków do oszczędności. Na początku lat 70. kraj zaczął przestawiać gospodarkę na przemysł lekki (włókienniczy, odzieżowy itp.). Następnie przemysł lekki zaczęto zmieniać bazowo na przemysł ciężki (budowlany, stoczniowy, chemiczny, elektromaszynowy itp.). Pod koniec XX w. rząd postanowił, żeby otworzyć nowe pole industrialne (przemysł bigh-tech, przemysł badawczo-rozwojowy) poza klasycznym rozwojem przemysłowym (przemysł wytwórczy: produkcja samochodów, sprzętu telewizyjnego, audio-wideo itp.).

Raport OECD (Organizacja Współpracy Gospodarczej i Rozwoju) z 1979 r. wprowadził termin „kraje nowo uprzemysłowione”"17. Ta grupa krajów wyróżnia się czterema głównymi cechami: 1) wzrostem stopy produkcji i zatrudnienia w krajowym sektorze przemysłowym; 2) wysoką stopą wzrostu PKB na mieszkańca (ale siła robocza w tych krajach nadal nie jest adekwatnie wynagradzana); 3) przyjęciem strategii wzrostu gospodarczego jako industrializacji napędzanej przez eksport; 4) szybką ekspansją udziału w światowej produkcji przemysłowej i eksporcie przemysłowym.

12 The World Bank, World Development Indicators: GDP (current US\$), http://databank.worldbank.org $/$ data $/$ reports.aspx? source $=2 \&$ country $=\&$ series $=$ NY.GDP.MKTP.CD\&period $=$ (dostęp: 15.01.2021).

13 W latach 1960-2016 liczba mieszkańców Korei Południowej wzrosła z $25 \mathrm{mln}$ do 51,2 mln.

14 UN, Economic Commission for Asia and the Far East, New York 1955.

15 D. Lasocka, Religia i tradycja. Filary koreańskiej rodziny [w:] Korea w oczach Polakón..., s. 431.

16 T. Goban-Klas, Korea. Historia..., s. 69.

17 OECD, The Impact of Newly Industrializing Countries in Production and Trade in Manufactures, Paris 1979. 
W tymże raporcie Korea Południowa, Tajwan, Singapur i Hongkong zostały nazwane ,azjatyckimi tygrysami”, które należą do „krajów nowo uprzemysłowionych" na terytorium Azji ${ }^{18}$. W Korei Południowej i w krajach Dalekiego Wschodu bardziej popularna nazwa to „cztery azjatyckie smoki”" ${ }^{19}$. W zachodnich krajach częściej używa się tego pierwszego określenia, gdyż to w Azji znajduje się siedlisko tygrysa, który jednocześnie jest postrzegany przez Zachód jako swoista ikona Azji. Tygrys symbolizuje siłę rozwoju gospodarki.

\section{Konfucjańska wartość w społeczeństwie}

Tradycyjne „konfucjańskie wartości” w Korei Południowej miały niewątpliwie silny wpływ na rozwój gospodarczy. Koreańskie społeczeństwo zawsze było częścią kultury konfucjańskiej. Wprawdzie wśród Koreańczyków nie funkcjonuje konfucjanizm jako religia, ale jest bardzo ważną ideą i do dziś wyraźnie odczuwa się jej wpływ na tamtejszą kulturę. Większość Koreańczyków w Korei Południowej $(56,1 \%)$ nie ma formalnego związku z religia. Wśród osób identyfikujących się z jakąs religią 19,7\% to protestanci, 15,5\% buddyści, a 7,9\% katolicy. Nieduży odsetek Koreańczyków z Korei Południowej (ogółem 0,8\%) stanowią wyznawcy innych religii, m.in. prawosławia ${ }^{20}$. W Korei zapewniona jest wolność religijna i w wielu rodzinach występują różne wyznania. Na przykład rodzice są buddystami, natomiast dzieci są chrześcijanami, przy czym nawet wśród rodzeństwa mogą być wyznawcy różnych religii.

Niezależnie od wyznawanej religii myślenie i postępowanie Koreańczyków jest silnie uwarunkowane wpływami konfucjanizmu, co wynika z jego filozoficznego aspektu. Bardzo trudno jest wyjaśnić konfucjanizm w jednym zdaniu, jednak można pokusić się o wyrażenie jego istoty za pomocą następującej zasady: gdy wszyscy kochają swych bliskich i darzą szacunkiem starszych, w rezultacie na całym świecie panuje pokój ${ }^{21}$. Dążenie do powszechnej harmonii dotyczy każdego aspektu życia w krajach Dalekiego Wschodu. Lee Hae-Sung, uwzględniając wymagania konfucjanizmu, określił charakter gospodarczo-kulturowy krajów Dalekiego Wschodu następująco: 1) wysoki poziom wykształcenia ludności; 2) silne więzi rodzinne;

18 Można określić to także jako „azjatycki model rozwoju”; H.S. Lee, Kapitalizm konfucjański. Koreańska droga roz̨woju, Toruń 2011, s. 81.

19 Termin ten był często używany do końca XX w. Potem zastosowanie tej metafory osłabło, ponieważ w 1997 r. w Azji Wschodniej zaczął się kryzys finansowy.

20 Portal statystyk krajowych (KOSIS), Ludność wedtug ptci, wieku, religii (seongbyeol/yeollyeongbyeol/ jonggyobyeol ingu) [성별/연령별/종교별 인구], http://kosis.kr/statHtml/statHtml.do?orgId=1 01\&tblId=DT_1PM1502\&conn_path=I2 (dostęp: 15.01.2021).

21 X. Yao, Konfucjanizm: wprowadzenie, tłum. J. Hunia, Kraków 2009, s. 182. 
3) wysokie wskaźniki oszczędności; 4) niski poziom konfliktów klasowych i pracowniczych; 5) współpraca między sektorem publicznym i prywatnym ${ }^{22}$.

W krajach, w których panuje konfucjanizm, życie i kontakty są oparte także na trzech ważnych elementach: wiek, dystans i kolektywizm. Dzięki nim społeczeństwo realizuje swój cel (tj. życie w harmonii). W przypadku Korei Południowej nawet sam język doskonale to obrazuje, idee konfucjanizmu wypełnia bowiem system grzeczności zwany „honoryfikatywnością”. Koreańczycy odpowiednio komunikuja się werbalnie albo niewerbalnie dzięki honoryfikatywności. W języku koreańskim różne formy gramatyczne i leksykalne są stosowane w zależności od wieku, stanowiska rozmówcy oraz dystansu pomiędzy rozmówcami. Z tego powodu starsza osoba i osoba mająca wyższe stanowisko mają większą władzę w społeczeństwie koreańskim. Dzięki takiej pionowej relacji rząd koreański mógł doprowadzić do szybkiego wzrostu gospodarczego w uporządkowanym społeczeństwie.

Ponadto dla Koreańczyków bardzo ważne jest odczuwanie wspólnotowości i patriotyzmu. Gdy rozmawiamy na wspólne tematy (np. rodzina, szkoła, kraj, firma itp.), używamy zaimka dzierżawczego „nasz” zamiast „mój”. To jednoznacznie ukazuje koreańską kolektywistyczną mentalność. Koreańczyk nie mówi „moja mama je” lub „Korea jest moim krajem”, w tym wypadku zwyczaje nakazują użycie zaimka „nasz”, więc mówi „nasza mama je” i „Korea jest naszym krajem”. Jeśli rozmawia się w języku koreańskim o żonie lub mężu, dla Polaków może brzmieć to nienaturalnie, a nawet wręcz dziwnie: „nasz mąż pracuje”. Natomiast w Korei Południowej wspólnota jest bardzo istotna, co dodatkowo potwierdzaja podświadomie niejako, zwyczajowo używane takie formuły językowe.

Ponadto kiedy Koreańczycy rozmawiają z obcymi ludźmi na ulicy (np. pytanie o czas, drogę), również używają formy adresatywnej związanej z rodzina. W Polsce do nieznajomej osoby zwracamy się z użyciem form „pani” lub „pan”. W Korei natomiast, jeżeli obca osoba jest 'starszą panią' lub 'starszym panem', można pozwolić sobie na zwrot „babciu” i „dziadku”, co w Polsce z kolei mogłoby wywołać oburzenie.

Dla Koreańczyków bowiem ważniejsze jest 'my' niż 'ja'. Takie językowe (wyrastające z konfucjańskiego myślenia) czynniki oddziałują na otaczającą rzeczywistość, a co za tym idzie - także na wzrost gospodarczy, ponieważ koreańskie społeczeństwo przez poczucie solidarności oraz wspólnoty chętnie poświęca i podporządkowuje swoje życie pracy. Koreańczycy sa przekonani, że miejsce pojedynczej osoby jest w zespole oraz że efekty przynosi tylko praca całej grupy ${ }^{23}$.

$\mathrm{Na}$ Dalekim Wschodzie istnieje stereotyp pracy (szczególnie w dużych firmach), zgodnie z którym „pracownik jest jak mrówka”, czyli cały dzień bardzo intensywnie pracuje w zespole. Kultura koreańska nie tylko uznaje to za słuszne, ale także

22 H.S. Lee, Kapitalizm konfucjanski..., s. 129-130.

23 A. Mościcka, Zarzadzanie zasobami lud₹kimi w aspekcie inwestycji koreańskich. Szanse i zagrożenia, „Gdańskie Studia Azji Wschodniej” 2012, z. 1, s. 143. 
zachęca do praktykowania takiego podejścia do pracy. W tabeli 1 przedstawiono zestawienie liczby godzin przepracowanych w roku przez Koreańczyków i Polaków.

Tab. 1. Porównanie roczne godziny pracy w Korei Południowej i w Polsce

\begin{tabular}{|l|c|c|c|c|c|c|c|}
\hline \multirow{2}{*}{ Kraj } & \multicolumn{7}{|c|}{ Liczba przepracowanych godzin w latach: } \\
\cline { 2 - 4 } & $\mathbf{2 0 0 0}$ r. & $\mathbf{2 0 0 1} \mathbf{r .}$ & $\mathbf{2 0 0 2} \mathbf{~ r . ~}$ & & $\mathbf{2 0 1 4} \mathbf{~ r .}$ & $\mathbf{2 0 1 5}$ r. & $\mathbf{2 0 1 6}$ r. \\
\hline Korea & 2512 & 2499 & 2464 & \multirow{2}{*}{$\ldots$} & 2075 & 2082 & 2069 \\
\hline Polska & 1988 & 1974 & 1979 & & 1923 & 1963 & 1928 \\
\hline
\end{tabular}

Źródło: OECD, Average annual hours actually worked per worker 2004-2016, https://stats.oecd.org/Index. aspx?DataSetCode=ANHRS (dostęp: 15.01.2021).

Korea do 2004 r. była krajem, w którym pracowało się najdłużej spośród wszystkich państw świata. Mimo że koreańskie społeczeństwo próbowało ograniczyć liczbe przepracowanych godzin, w 2016 r. Korea nadal zajmowała pod tym względem 3. miejsce, zaraz po Meksyku i Kostaryce. Dlatego 1 lipca 2018 r. koreański rząd ogłosił ustawę o normach prac ${ }^{24}$, w której art. 51 wskazano jako przeciętną tygodniową normę pracy -52 godziny (wcześniej było 68 godzin w tygodniu). W Polsce zgodnie z art. 129 kodeksu pracy czas pracy wynosi 8 godzin dziennie i 40 godzin tygodniowo w pięciodniowym tygodniu pracy w przyjętym okresie rozliczeniowym.

To wcale nie znaczy, że Koreańczycy lubią spędzać dużo czasu w pracy. Przyczyny tego zjawiska są także zakorzenione w konfucjanizmie. Występują w nim bowiem ważne relacje zależnościowe: 'ojciec - syn', 'starszy brat - młodszy brat', 'mąż - żona', 'kolega - kolega', 'władca - podwładny'25. Jeżeli każda z tych relacji opiera się na wzajemnym szacunku, to wszelkie konflikty i problemy zostaną rozwiązane. Te zasady moga być zastosowane także we współczesnym społeczeństwie. Relacje 'ojciec - syn' lub 'władca - podwładny' można zastapić relacją 'szef - pracownik'. Wówczas firma staje się odbiciem domu w konfucjańskiej kulturze. Z tego względu powstało popularne w Korei Południowej określenie, w myśl którego „praca jest rodziną”. Firmy koreańskie charakteryzuje o wiele mocniejsza relacja zwierzchnictwa dyrektorów nad swoimi pracownikami niż w firmach amerykańskich czy europejskich: „Na skutek paternalistycznego nastawienia do pracowników nie uczestniczą oni w ogóle lub są bardzo ograniczeni w procesie decyzyjnym"26. Charakter koreańskiej firmy można zdefiniować takimi terminami, jak: hierarchiczność, przywództwo, zależność ${ }^{27}$.

Koreańska grzeczność znajduje swoje miejsce w hierarchii, co jest widoczne w koreańskim etosie pracy. Ze względu na cechy tamtejszego społeczeństwa

\footnotetext{
24 Pisownia w języku koreańskim 근로기준법 제51조 (geullogijunbeop je 51 jo).

25 H.S. Lee, Kapitalizm konfucjanski..., s. 40-41.

26 A. Grycuk, Wspótpraca zinwestorem koreańskim, „PAIiIZ i Partnerzy” 2005, nr 21, s. 6.

27 I. Terefenko, Kultura narodowa w zarzadzaniu miężynarodonym, „Edukacja dla Bezpieczeństwa” 2018, nr 4, s. 169-170.
} 
i koreańskiej kultury, w których ważne są relacje hierarchiczne, w koreańskich firmach istnieją bardzo odmienne stanowiska w porównaniu do firm europejskich. Jeśli pracownik koreańskiej firmy nie jest biegły w rozumieniu form adresatywnych, to może wywołać różne problemy, ponieważ nie zrozumie decyzji korporacyjnych i struktur komunikacyjnych. Poznanie systemu grzeczności jest kluczem do zrozumienia kultury i zasad funkcjonowania firmy koreańskiej.

Jednak dziś w młodym pokoleniu zasady się zmieniły. Przed kryzysem gospodarczym z 1997 r. sytuacja na rynku pracy w Korei Południowej wyglądała tak, że kiedy pracownik zaczynał pracować w jednej firmie, zazwyczaj pozostawał w niej do emerytury. Z tego powodu pojawiła się koncepcja „praca całego życia” (평 생 직장). Współcześnie nie jest ona już powszechna ${ }^{28}$. W 2018 r. to koncepcja WLB, Work and Life Balance ${ }^{29}$ (równowaga w pracy i życiu) zyskała na popularności w społeczeństwie koreańskim. WLB opiera się na racjonalnym podejściu do czasu pracy, ponieważ wydajność pracownika spada w przypadku częstych nadgodzin. W związku z powyższym wśród poszukujących pracy pojawiła się nowa tendencja - elastyczność czasu pracy stała się ważniejsza niż wysokie wynagrodzenie ${ }^{30}$.

W koreańskiej firmie obiad jest spożywany wspólnie z pracownikami. Ponieważ praca kończy się zwykle bardzo późno, należy zjeść także wspólnie kolację. Bardzo często po pracy pracownicy wciąż są zobowiązani do udziału w boe-sik $k^{31}$ (dosł. 'obiad personelu') $)^{32}$, na który całe firmy udają się do baru lub restauracji. Koreańczycy rozumieją hoe-sik jako „firmową integrację” (obiad lub kolację z pracownikami po godzinach pracy, co wiąże się też ze wspólnym piciem alkoholu). Takie kolacje zazwyczaj są sponsorowane przez firmę lub szefa. Przez długi czas „firmowa integracja” była symbolem życia w koreańskiej firmie. Hoe-sik ma pewne aspekty współpracy i jedności, ale można go również rozumieć jako przedłużenie pracy ${ }^{33}$. Obecnie młodsze pokolenie już nie chce się zgadzać na tego rodzaju integrację, więc wyjścia z szefem stają się mniej popularne. Wedle raportu Ministerstwa Kul-

28 평생직장이 어딨나요? 신입사원 80\% ‘이직준비생' (pyeongsaengïkjangi eodinnayo? sinipsawon 80\% 'ijikjunbisaeng', „Edaily”) [Gdzie jest praca całego życia? 80\% nowych pracowników przygotowuje się do zmiany pracy], https://www.edaily.co.kr/news/read?newsId=01197206622 487280\&mediaCodeNo=257 (dostęp: 15.01.2021).

${ }^{29}$ W języku koreańskim to pojęcie brzmi war-ra-bel (워라밸). Wyróżnione są tylko pierwsze sylaby słów: Work, Life, Balance, czyli wor, li, bal.

30 WLB zaczęło pojawiać się w koreańskich mediach ok. 2017 r.

31 Pisownia w języku koreańskim 회식.

32 W słowniku koreańskim to słowo jest definiowane następująco: „kilka osób zbiera się, aby jeść razem lub takie spotkanie”. Natomiast Koreańczycy myślą o nim jako o „firmowej integracji”: pracownicy muszą wraz z prezesem jeść posiłki zakrapiane alkoholem, po regularnych godzinach pracy; F. Ahrens, Koreańczyycy. W pułapce doskonatości, tłum. A. Czwojdrak, Kraków 2017, s. 119.

33 E.J. Jeon, 직장 내 의사소통의 양상과 개선 방향 (jikjang nae misasotongui yangsanggwa gaeseon banghyang) [Aspekty komunikacji w pracy i kierunek poprawy], 새국어 생활 (Saegugeosaenghwal) [Nowe życie języka koreańskiego] 2018, no. 28-1, s. 35. 
tury, Sportu i Turystyki czterech na dziesięciu pracowników w Korei Południowej uważa kulturę ho-esik za nieprzyjemny obowiązek ${ }^{34}$. Takie spotkania Koreańczyków zwykle okraszone są sporą ilością alkoholu, podczas nich rozmawia się o konfliktach w pracy i nawiązuje lepsze relacje ze współpracownikami. Są one też traktowane jako okazja do załagodzenia jakichś sporów lub rozwiązania problemów z osobą na wyższym stanowisku ${ }^{35}$.

\section{Kultura picia}

W Korei Południowej istnieje kilka zasad picia alkoholu. Sa traktowane jako swoiste prawo zwyczajowe. Powinno się ich przestrzegać nie tylko na spotkaniach służbowych, ale także na spotkaniach rodzinnych czy akademickich. Koreańczycy nazywają te reguły „kultura picia” ${ }^{6}$ lub „zasadami picia”. Zazwyczaj uczą się ich od starszych członków rodziny. Muszą być przestrzegane od momentu wejścia na miejsce spotkania. Goście powinni zostać posadzeni z zachowaniem ich rangi. Najważniejszy z nich otrzymuje honorowe miejsce (zazwyczaj na środku lub najwygodniejsze). Podczas spotkań biznesowych szefowie siedzą naprzeciw siebie ${ }^{37}$. Co ważne, kultura picia stanowi kolejny przykład znaczenia wartości konfucjańskich w społeczeństwie koreańskim. Jak pisze I. Janicka: „Etykieta picia i gestów towarzyszących spożywaniu alkoholu szczególnie wyraziście ukazuje panowanie zasad konfucjańskich w codziennym życiu. Należy przy tym odróżnić sytuację towarzyską rówieśniczą od formalnej sytuacji zhierarchizowanej. W tym drugim przypadku bowiem nalewanie i picie alkoholu to czynność obwarowana określonymi rytuałami"38.

Wspomniane rytuały można pokrótce zmieścić w trzech punktach:

1) Alkohol nalewa się w kolejności zgodnej z hierarchią w danej firmie. Podczas picia nie można samemu sobie nalewać alkoholu. Trzeba czekać do momentu, gdy ktoś inny ma pusty kieliszek, by go napełnić. Czasami dopuszczalne jest, by starsza osoba sama nalała sobie alkohol, ale jest to niedopuszczalne w przypadku osób młodszych. Tego rodzaju rytuały mają na celu w sposób symboliczny wyrazić wzajemne dbanie braci o siebie ${ }^{39}$.

\footnotetext{
34 2014년 일하는 방식과 문화에 대한 인식조사 보고서 (2014 nyeon ilhaneun bangsikgwa munhwae daehan insikjosa bogoseo) [Ministerstwo Kultury, Sportu i Turystyki, Badanie śniadomości pracy i kultury w 2014 rokul, Seul 2014, s. 23.

35 F. Ahrens, Koreańcsycy. W pułapce..., s. 119.

36 Ibidem, s. 119.

37 A. Grycuk, Wspótpraca z. inwestorem..., s. 3.

38 I. Janicka, Komunikacja niewerbalna Koreańcayków na tle tradycji kulturowej. Perspektywa glottodydaktyczna, „Poznańskie Studia Polonistyczne” 2009, t. 15, s. 18.

39 Ibidem, s. 19.
} 
2) Osobie starszej lub na wyższym stanowisku należy nalewać alkohol dwiema rękami, a w sytuacji, gdy ktoś taki nalewa alkohol nam, wówczas trzeba podać swój kieliszek także oburąc ${ }^{40}$. Jeśli mamy napełnić kieliszek osoby o podobnej randze lub niższej rangą, możemy to zrobić jedną ręka. Drugą rękę można położyć w pobliżu, żeby gest nie był odczytany jako arogancki.

3) Kiedy pijemy ze starszą osobą alkohol, należy obrócić głowę w przeciwną stronę przy przechylaniu kieliszka.

\section{Służba wojskowa}

Od wojny koreańskiej do chwili obecnej w Korei Południowej służbę wojskowa obowiązkowo muszą odbyć prawie wszyscy mężczyźni (od 18. roku życia) posiadający obywatelstwo koreańskie ${ }^{41}$. Ten obowiązek opiera się na art. 39 Konstytucji Republiki Korei oraz art. 3 ust. 1 ustawy o prawie służb wojskowych. Korea nie pozwala na posiadanie wielokrotnego obywatelstwa, co jest związane m.in. z obowiązkiem wojskowym. Wybierając obywatelstwo koreańskie, Koreańczycy zgadzaja się na obowiązek służby wojskowej. Dorośli Koreańczycy automatycznie są włączeni do służby wojskowej bez względu na swój zawód, status społeczny albo rodzaj pracy (kobiety nie są do tego zobowiązane, tylko ochotniczo). Nie ma znaczenia, czy dana osoba jest studentem, aktorem, pracownikiem fizycznym, sportowcem czy sławnym piosenkarzem. Służba ochrony państwa jest jednym z czterech obowiązków narodu Republiki Korei (art. 31 ust. 1 i ust. 2 Konstytucji Republiki Korei) ${ }^{42}$. W ostatnich latach znacznie osłabła wśród obywateli ${ }^{43}$ ochota na wstępowanie do wojska, ale nadal wiele osób twierdzi, że służba wojskowa jest najważniejszym obowiązkiem mężczyzn wobec Korei Południowej.

Ma ona ogromny wpływ na modelowanie współczesnej kultury koreańskiej oraz mentalności Koreańczyków, w tym na kształtowanie silnie hierarchicznych zależności w społeczeństwie. Wydaje się, że w tym zakresie odegrała nawet większą rolę niż

40 P. Wierzchoń, Koreańcsyyk grzeczny jest [w:] Grzeczność na kerańcach świata, red. M. Marcjanik, Warszawa 2007, s. 114.

41 Mężczyzna może wnioskować o zwolnienie ze służby wojskowej, jeśli: cierpi na ciężką chorobę, musi wziąć odpowiedzialność za utrzymanie swojej rodziny lub odbywa karę pozbawienia wolności na okres ponad 1,5 roku.

42 Pozostałe trzy uregulowane w Konstytucji Republiki Korei to: obowiązek edukacji (art. 31 ust. 2), obowiązek pracy (art. 32 ust. 2) i obowiązek podatku (art. 38). Zob. Konstytucja Republiki Korei, przekład z jęz. koreańskiego A. Diniejko, wprowadzenie i konsultacja merytoryczna M.M. Wiszowaty, Gdańsk 2015.

43 B.J. Kim, S.J. Kim, S.N. Cho, 군(軍)에 대한 인식격차 연구: 성별 · 세대별 차이를 중 심으로 (gune daehan insikgyeokcha yeongu: seongbyeol sedaebyeol chaireul jungsimeuro) [Badanie luki w postrzeganiu dla wojska: koncentracja na różnicach płci i pokoleń], „Journal of Defense Policy Studies" 2013, no. 29-4, s. 238-239. 
konfucjanizm. Przez to koreańska kultura różni się od innych kultur Azji Wschodniej. Większość męskich członków społeczeństwa służyło w wojsku i doświadczyło relacji pionowej w stylu militarnym. Sposób myślenia charakterystyczny dla wojska odnosi się też do późniejszego myślenia w pracy. Z tego powodu relacje służbowe w Korei Południowej mają charakter militarny, a sami Koreańczycy uważają, że ci, którzy byli w wojsku, są lepiej przygotowani do pracy, ponieważ są bardziej cierpliwi i skłonni do poświęceñ ${ }^{44}$. Taka tendencja społeczna jest widoczna nawet w organizacjach składających się wyłącznie z kobiet - te grupy również mają charakter militarny. Całe społeczeństwo przyzwyczaiło się do organizacji wojskowej.

Podsumowując, służba wojskowa mocno wpływa na mentalność Koreańczyków w Korei Południowej. W tak uformowanym koreańskim społeczeństwie widzimy zalety i wady. Zaleta jest synergia, która łączy się z innymi elementami kulturowymi (konfucjanizm, kolektywizm, patriotyzm). Z tego powodu Koreańczycy pracują bardzo skutecznie pod przywództwem lidera. Jak bowiem zauważa A. Grycuk: „Charakterystyczny dla korporacyjnej Korei autokratyczny styl zarządzania wymaga silnego i zdecydowanego przywództwa"45.

\section{Okcydentalizacja}

Korea Południowa jest popularnym przykładem dynamicznego, dokonanego w bardzo krótkim czasie rozwoju gospodarczego od poziomu ubóstwa do kraju wysoko rozwiniętego. Kraj osiagnął sukces gospodarczy w ciagu pół wieku. Równocześnie wzrosła szybko populacja, a demokracja zachodnia została pomyślnie zaadaptowana. Taki rozwój gospodarczy nastąpił niewątpliwie pod wpływem kultury zachodniej, zwłaszcza amerykańskiej. Jest to sytuacja podobna do Polski po upadku komunizmu. Spośród trzech krajów Azji Wschodniej: Chiny, Japonia i Korea, to właśnie Korea Południowa najbardziej się zokcydentalizowała. Nie dotyczy to systemu społecznego ani skali ekonomicznej. Okcydentalizacja w przypadku Korei Południowej oznacza zerwanie z tradycyjną kultura. Ironicznie mówiąc, kraj ten osiagnął szybki rozwój dzięki oparciu się na tradycji kultury konfucjańskiej, ale równie szybko stracił swoją kulturę w wyniku tego rozwoju. Wraz z nadejściem ery Internetu zjawisko to jeszcze bardziej przyspieszyło ${ }^{46}$. Społeczeństwo koreańskie jest pod silnym wpływem Internetu ${ }^{47}$.

${ }^{44}$ Do pierwszych lat XXI w. koreańskie firmy faworyzowały pracowników po wojsku, nawet w przypadku pracy dorywczej.

45 A. Grycuk, Wspótpraca z.inwestorem..., s. 1.

46 P. Wierzchoń, Koreańczyyle grzeczny..., s. 112.

47 Internet Korei Południowej ma jedna z najwyższych prędkości na świecie (Akamai, Q1 2017 State of the Internet - Connectivity Report, https://wwwakamai.com/de/de/multimedia/documents/state-of-the-internet/q1-2017-state-of-the-internet-connectivity-report.pdf (dostęp: 15.01.2021). 
Taka westernizacja ma ogromny wpływ również na język. Mimo że honoryfikatywność odgrywa najważniejszą rolę w kulturze koreańskiej, to westernizacja nawet na tym polu doprowadziła do wielu zmian. We współczesnej rodzinie koreańskiej tradycyjna grzeczność językowa występuje już w bardziej ograniczonych formach niż kiedyś. Na przykład w latach 90. XX w. dzieci zazwyczaj musiały się zwracać do rodziców z użyciem grzecznościowej formy, natomiast obecnie jest to rzadko spotykane. Przykładowe zdania:
1) eomeoni, jeoneun baegopayo
어머니, 저는 배고파요.
2) eomma, naneun baegopa $\underline{\underline{0}}$ 엄마, 나는 배고파.

Oba zdania można przetłumaczyć na język polski jako 'mamo, jestem głodny'. Pierwsze zdanie jest grzeczniejsze, w nim honoryfikatywność obejmuje adresata: 'mama’ i podmiot ‘ja' oraz orzeczenie 'być głodnym’. Użycie honoryfikatywności wpływa na odczucie dystansu ze strony dziecka, jednak dla rodziców jest to odpowiednio grzeczne zachowanie. Akceptacja takich form wynika z relacji między Koreańczykami, która opiera się na „bliskości ze względu na dystans”. Różni się od „bliskości opartej na bezpośredniości”, która jest podstawą stosunków polskich. Z tego powodu dla Koreańczyków ważna jest odległość w stosunkach międzyludzkich. Z kolei w drugim zdaniu nie występuje żadna z form grzecznościowych. Teoretycznie taki sposób zwracania się do rodziców jest niegrzeczny, jednak dziś już stał się akceptowalny w społeczeństwie. Chociaż jeszcze „bliskość ze względu na dystans" panuje w innych sytuacjach społecznych w Korei Południowej, to relacja rodzinna zamienia się na „bliskość opartą na bezpośredniości”. Zmiany te mają też wpływ na nazywanie pokrewieństwa rodzinnego. Koreańskie relacje rodzinne sa upraszczane na podobieństwo europejskich.

\section{Podsumowanie}

Aktualnie Korea Południowa jest krajem kontrastów. Z jednej strony nadal zauważalna jest kultura konfucjańska oraz „koreańska” konserwatywna honoryfikatywność (przede wszystkim hierarchia zależy od wieku), z drugiej zaś strony młodzież pragnie relacji poziomej, jak w zachodniej kulturze. Koreańskie społeczeństwo radykalnie zmieniło się na przełomie XX i XXI w., co przełożyło się na silny wpływ kultury zachodniej (szczególnie amerykańskiej) na koreańską. Koreańska grzeczność opierająca się na współczesnej mentalności ma różne źródła, do których należy zaliczyć przede wszystkim konfucjanizm, gwałtowny rozwój gospodarczy, nawet polityczno-ideologiczny konflikt z Koreą Północną (tj. służba wojskowa) oraz teraźniejszą falę globalizacji. 


\section{SUMMARY}

\section{SELECTED COMPONENTS OF CONTEMPORARY KOREAN MENTALITY RELATED TO POLITENESS}

In the twentieth century, Korea had a violent change in its history. Initially, Korea lost its independence and became a Japanese colony. It regained freedom after the defeat of Japan, but soon, the Korean War broke out. From that time until today, Korea has been divided into two parts: the southern one and the northern one. After the war, South Korea was a country under military dictatorship for a long time. South Korea after the Korean War belonged to one of the poorest countries over the world. In the present time, however, South Korea has become a country that has a great impact on the global economy. This change in history had a huge impact (positively and negatively) on the mentality of Koreans. The aim of my article is to present the economic development of South Korea from a Confucian point of view and to analyze the impact of Korean history in the twentieth century on the mentality of Koreans and its operation in Korean society (work ethos and ethos of science, Korean language, etc.). 